P-ISSN: E-ISSN:

Email: ristansi@asia.ac.id

https://jurnal.stie.asia.ac.id/index.php/ristansi

\title{
PENGARUH RETURN ON EQUITY(ROE), DEBT TO EQUITY RATIO(DER), DAN CURRENT RATIO(CR) TERHADAP RETURN SAHAM PERUSAHAAN SUB SEKTOR PROPERTY DAN REAL ESTATE YANG TERDAFTAR DI BURSA EFEK INDONESIA
}

\author{
Justita Dura, Febi Vionitasari \\ Institut Teknologi dan Bisnis Asia Malang \\ Alamat surel : justitadura@asia.ac.id
}

DOI: doi.org// $\mathrm{xxxxx}$

Informasi Artikel

Tanggal Masuk November $17^{\text {th }}, 2020$

Tanggal Revisi

Tanggal diterima $29^{\text {th }} 2020$ December $10^{\text {th }}, 2020$

Keywods:

Return On

Equity (ROE),

Debt to Equity

Ratio (DER),

Current Ratio

(CR), Return

Saham

\begin{abstract}
:
The influene on Return On Equity (ROE), Debt to Equity Ratio (DER), and Current Ratio (CR) on company stock returns included the company of the sub sector property and real estate listed in Indonesia Stock Exchange (IDX).

This study aims to determine the effect of Return On Equity (ROE), Debt to Equity Ratio (DER), and Current Ratio (CR) on stock returns. This research was conducted with a quantitative method on the financial statements of companies listed in Indonesia Stock Exchange (IDX) during the period 2016-2018. The total sample of the study was 24 companies, which were determined through a purposive sampling method. The data used are secondary data namely the financial statements of the sub sector property and real estate listed in Indonesia Stock Exchange. The analysis technique used in this study is multiple linear regression with SPSS tools 23.

Independent variables are, Return On Equity (ROE), Debt to Equity Ratio (DER), and Current Ratio (CR), while the dependent variable is the stock return. The test of Return On Equity (ROE) does not affect stock returns. The Debt to Equity Ratio (DER) test does not affect stock returns. Test the Current Ratio (CR) does not affect stock returns.
\end{abstract}

Kata Kunci:

Return On

Equity (ROE),

Debt to Equity

Ratio (DER),

Current Ratio

(CR), Return

Saham

\begin{abstract}
Abstrak:
Pengaruh Return On Equity (ROE), Debt to Equity Ratio (DER), dan Current Ratio (CR) Terhadap Return Saham Perusahaan Sub Sektor Property dan Real Estate yang Terdaftar di Bursa Efek Indonesia.

Penelitian ini bertujuan untuk mengetahui pengaruh Return On Equity (ROE), Debt to Equity Ratio (DER), dan Current Ratio (CR) terhadap return saham. Penelitian ini dilakukan dengan metode kuantitatif terhadap laporan keuangan perusahaan yang terdaftar di Bursa Efek Indonesia selama periode 2016-2018. Total sampel penelitian adalah 24 perusahaan, yang ditentukan melalui
\end{abstract}


metode purposive sampling. Data yang digunakan adalah data sekunder yaitu laporan keuangan perusahaan sub sektor property dan real estate yang terdaftar di Bursa Efek Indonesia. Teknik analisis yang digunakan dalam penelitian ini adalah regresi linear berganda dengan alat bantu SPSS 23.

Variabel independen adalah Return On Equity (ROE), Debt to Equity Ratio (DER), dan Current Ratio (CR), sedangkan variabel dependen adalan return saham. Uji Return On Equity(ROE) tidak berpengaruh terhadap return saham. Uji Debt to Equity Ratio (DER) tidak berpengaruh terhadap return saham. Uji Current Ratio (CR) tidak berpengaruh terhadap return saham.

\section{PENDAHULUAN}

\subsection{Latar Belakang Masalah}

Seorang investor dalam berinvestasi memiliki tujuan utama untuk mendapatkan hasil yang diperoleh dari investasi (return). Setiap tahunnya return yang diterima oleh pemegang saham perusahaan selalu mengalami fluktuasi, sehingga para investor membutuhkan informasi mengenai perusahaan dari laporan keuangan.

Informasi dalam memberikan sinyal bagi investor tentang prospek perusahaan dimasa mendatang. Teori sinyal (signalling theory) yang dikembangkan oleh Ross (1977) menyatakan bahwa pihak eksekutif perusahaan memiliki informasi lebih baik mengenai perusahaannya akan terdorong untuk menyampaikan informasi tersebut agar para investor harga saham perusahaannya meningkat.

Rasio keuangan memiliki pengaruh dan hubungan yang kuat dengan harga saham. Rasio keuan karena rasio keuangan merupakan perbandingan antar akun dalam laporan keuangan. Dalam informasi yang tercermin pada laporan keuangan, para stakeholder akan dapat menilai kinerja perusahaan dalam mengelola bisnisnya, yang berakhir pada fluktuasi perubahan harga saham dan return saham.

Untuk memprediksi return saham, banyak faktor yang dapat digunakan sebagai parameter antara lain adalah informasi keuangan perusahaan dan informasi pasar atau saham. Informasi keuangan dan informasi pasar yang dapat digunakan untuk memprediksi return saham diantaranya: Return On Equity, Debt to Equity Ratio, dan Current Ratio.

Menurut Kasmir $(2016 ; 204)$ semakin tinggi nilai ROE maka kinerja perusahaan dianggap semakin baik dan posisi perusahan akan semakin kuat, demikian pula sebaliknya. Jika ROE meningkatnya artinya perusahaan dianggap mampu menghasilkan laba yang tinggi dan menumbuhkan perusahaan dengan menggunakan uang dari pemegang saham secara efisien. Memperoleh laba yang tinggi dapat meningkatkan harga saham perusahaan. Terjadinya peningkatan harga saham berakibat pula pada peningkatan return saham yang diterima pemegang saham. Didukung dari penelitian Sepriana dan Saryadi (2017), Aisah dan Mandala (2016), serta Antara, dkk (2014) bahwa ROE berpengaruh signifikan terhadap return saham. Penelitian Susilowati dan Turyanto (2011) menemukan hasil yang berbeda, bahwa ROE tidak berpengaruh terhadap return saham.

Menurut Kasmir $(2016 ; 157)$ Debt to Equity Ratio merupakan rasio yang digunakan untuk mengetahui jumlah dana yang disediakan kreditur dengan pemilik perusahaan atau untuk mengetahui jumlah rupiah modal sendiri yang dijadikan untuk jaminan utang. Seorang kreditur, semakin besar rasio maka semakin tidak menguntungkan karena akan 
semakin besar risiko yang ditanggung atas kegagalan yang terjadi di perusahaan. Jika, semakin tinggi DER cenderung menurunkan return saham, karena tingkat hutang yang semakin tinggi menunjukkan beban bunga perusahaan akan semakin besar dan mengurangi keuntungan. Hal ini sesuai penelitian Purwitajati dan Putra (2016), Anisa (2015) DER berpengaruh signifikan terhadap return saham. Namun berbeda dengan penelitian Darajat (2018) bahwa DER berpengaruh negatif terhadap return saham. Sedangkan, penelitian Hayat (2014), Sepriana dan Saryadi (2017) DER tidak berpengaruh terhadap return saham.

Current Ratio (CR) adalah rasio untuk mengukur kemampuan perusahaan dalam membayar kewajiban jangka pendek atau utang yang segera jatuh tempo pada saat ditagih secara keseluruhan (Kasmir, 2016;134). Current Ratio yang rendah biasanya dianggap menunjukkan terjadinya masalah dalam likuidasi, sebaliknya Current Ratio yang terlalu tinggi juga kurang bagus, karena menunjukkan banyaknya dana menganggur yang pada akhirnya dapat mengurangi kemampuan perusahaan. Hal ini menunjukkan bahwa investor akan memperoleh return yang lebih rendah jika kemampuan perusahaan memenuhi kewajiban jangka pendeknya semakin rendah. Didukung dari penelitian Antara, dkk (2014), dan Hayat (2014) Current Ratio tidak berpengaruh terhadap return saham. Penelitian Sugiarti dan Surachman (2015) Current Ratio berpengaruh negatif terhadap return saham.

Pertumbuhan sektor property masih sulit dengan angka di atas pertumbuhan ekonomi nasional. Hal ini disebabkan karena banyaknya aturan yang tidak jelas dan membuat para pelaku industri property waspada. Peneliti memilih perusahan sub sektor property dan real estate sebagai objek penelitian apakah melemahnya sektor property dan real estate mempengaruhi harga saham perusahaan yang kemudian juga akan berpengaruh terhadap return saham perusahaan. Berdasarkan pemaparan penelitian sebelumnya, masih terdapat ketidakkonsistenan hasil penelitian sehingga perlu dilakukan penelitian lebih lanjut dengan judul penelitian adalah Pengaruh Return On Equity (ROE), Debt to Equity Ratio (DER), dan Current Ratio (CR) Terhadap Return Saham Perusahaan Sub Sektor Property dan Real Estate yang berdaftar di Bursa Efek Indonesia.

Rumusan masalah dalam penelitian ini adalah bagaimana pengaruh Return On Equity (ROE), Debt to Equity Ratio (DER), dan Current Ratio (CR) terhadap return saham.

\subsection{Tinjauan Pustaka Teori Sinyal}

Menurut Ross (1977) teori sinyal menyatakan bahwa pihak eksekutif perusahaan memiliki informasi lebih baik mengenai perusahaannya akan terdorong untuk menyampaikan informasi tersebut kepada calon investor agar harga saham perusahaannya meningkat. Informasi keuangan sangat penting bagi investor dan pelaku bisnis karena informasi pada hakekatnya menyajikan keterangan, catatan atau gambaran, baik untuk keadaan masa lalu, masa kini maupun masa yang akan datang demi kelangsungan hidup perusahaan.

\section{Analisis Fundamental}

Analisis fundamental adalah analisis harga saham yang menitikberatkan pada kinerja perusahaan yang mengeluarkan saham dan analisis ekonomi yang akan mempengaruhi masa depan perusahaan, diharapkan calon investor akan mengetahui operasional perusahaan yang nantinya menjadi milik investor. Apabila kinerja perusahaan mengalami perkembangan yang baik maka harga saham akan meningkat. Menurut Hermuningsih $(2012 ; 194)$ analisis fundamental merupakan usaha untuk 
memperkirakan kesehatan dan prospek dalam kemampuan suatu perusahaan untuk bertumbuh dan menghasilkan laba di masa depan.

\section{Saham}

Saham merupakan salah satu instrumen pasar modal yang paling banyak diminati oleh investor karena mampu memberikan tingkat pengembalian yang menarik. Saham dibagi menjadi dua jenis yaitu saham biasa dan saham preferen.

Menurut Jogiyanto $(2014 ; 7)$ dengan adanya risiko yang besar biasanya jika usaha perusahaan berjalan baik maka dividen saham biasa akan lebih besar dari pada saham preferen. Tetapi jika terjadi likuidasi pembagian dividen dan pembagian harta perusahaan serta pemegang saham biasa akan memperoleh pembagian terakhir setelah pemegang saham preferen.

\section{Return Saham}

Menurut Jogiyanto $(2014 ; 205)$ return merupakan hasil yang diperoleh dari investasi. Return saham dibedakan menjadi dua yaitu return dapat berupa realisasi (realized return) yang sudah terjadi. Return realisasi dihitung menggunakan data historis. Return ekspektasi (expected return) yang belum terjadi tetapi yang diharapkan akan diperoleh investor terjadi dimasa mendatang.

Adapun prediksi sederhana yang biasa digunakan untuk mengetahui kecenderungan harga saham, yakni dengan memperhatikan harga penutupan (closing price) yang muncul saat bursa tutup. Prediksi harga penutupan dapat membantu investor untuk mengetahui berapa nilai beli (offer) dan nilai jual (bid) yang sedang terjadi di bursa efek. Harga penutupan menjadi penting untuk diperhatikan karena digunakan sebagai acuan harga pembukaan (opening price) di hari berikutnya. Menurut Jogiyanto (2014;206) return saham terdiri dari dua komponen yaitu:

\section{Capital Gain (loss)}

Capital gain (loss) merupakan selisih utang (rugi) dari harga investasi sekarang relatif dengan harga pokok periode yang lalu.

Yield

Capital Gain (Loss)=Harga jual-harga beli $\times$ jumlah lembar saham

Yield merupakan nilai persentase penerimaan kas periodik terhadap harga investasi periode tertentu dari suatu investasi.

Yield $=\mathrm{Dt} /(\mathrm{Pt}-1)$

Secara sistematis, perhitungan return saham menurut Jogiyanto (2014;207) adalah:

Pt - Pt-1

Pt-1

\section{Rasio Keuangan}

Menurut Kasmir (2016;104) rasio keuangan merupakan suatu kegiatan membandingkan angka-angka yang ada di dalam laporan keuangan.

\section{Return On Equity(ROE)}

Menurut Kasmir (2016;204) Return On Equity merupakan rasio untuk mengukur laba bersih sesudah pajak dengan modal sendiri. Rasio ini menunjukkan efisiensi penggunaan modal sendiri. Semakin tinggi ROE semakin baik. Artinya perusahaan berhasil menghasilkan keuntungan dari modalnya sendiri dan posisi pemilik perusahaan semakin kuat, demikian pula sebaliknya. Meningkatnya ROE akan mendongkrak nilai jual perusahaan yang berimbas pada harga saham, hal ini berkorelasi dengan peningkatan return saham. Return On Equity diukur dengan rumus:

$\mathrm{ROE}=($ Laba bersih setelah pajak $) /($ Total ekuitas $) \times 100 \%$

Debt to Equity Ratio (DER) 
Menurut Kasmir $(2016 ; 157)$ Debt to Equity Ratio merupakan rasio yang digunakan untuk menilai utang dengan ekuitas dan untuk mengetahui jumlah dana yang disediakan peminjam (kreditor dengan pemilik perusahaan). Dengan kata lain, DER berfungsi untuk mengetahui setiap rupiah modal sendiri yang dijadikan untuk jaminan utang. Semakin tinggi DER akan semakin tinggi kemampuan perusahaan untuk membayar seluruh kewajibannya. Semakin besar proporsi utang yang digunakan untuk struktur modal suatu perusahaan, maka semakin besar pula jumlah kewajibannyaRumus yang digunakan:

$\mathrm{DER}=($ Total liabilitas $) /($ Total Ekuitas $)$

\section{Current Ratio (Rasio lancar)}

Menurut Kasmir (2016;134) rasio lancar atau Current Ratio merupakan rasio yang digunakan untuk mengukur kemampuan perusahaan dalam membayar kewajiban jangka pendek atau utang yang segera jatuh tempo pada saat ditagih secara keseluruhan. Mengukur banyaknya aset lancar yang tersedia untuk menutupi kewajiban jangka pendek atau utang yang segera jatuh tempo. Rumus rasio lancar adalah:

Current Ratio $=($ Aset lancar $) /($ Utang lancar $) \times 100 \%$

\section{Kerangka Konseptual}

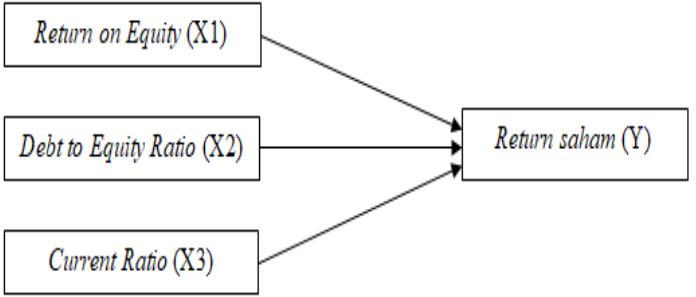

\subsection{Hipotesis}

$\mathrm{H}_{1}$ : Return On Equity (ROE) berpengaruh terhadap return saham

$\mathrm{H}_{2}$ : Debt to Equity Ratio (DER) berpengaruh terhadap return saham

$\mathrm{H}_{3}$ : Current Ratio (CR) berpengaruh terhadap return saham

\section{METODE PENELITIAN}

Jenis penelitian ini merupakan penelitian asosiatif kausal. Penelitian asosiatif kausal adalah penelitian yang bertujuan untuk mengetahui pengaruh antar variabel (Bahri, 2018;18). Penelitian ini menggunakan pendekatan kualitatif yang menekankan pada data numeric yang diolah dengan metode statistik.

Populasi merupakan keseluruhan objek penelitian dan memenuhi karakteristik tertentu (Bahri, 2018;49). Populasi penelitian adalah perusahaan sub sektor property dan real estate di Bursa Efek Indonesia periode 2016-2018.

Sampel merupakan bagian dari populasi yang diambil melalui pemilihan karakteristik tertentu. Sampel akan diambil jika peneliti tidak sanggup untuk melakukan penelitian dengan mengambil data langsung dari populasi (Efferin, dkk., 2008;73 dalam Bahri, 2018;51) penggunaan sampel penelitian menggunakan metode purposive sampling. Purposive sampling merupakan salah satu teknik pemilihan dengan didasarkan pada kriteria tertentu dengan tujuan untuk memberikan informasi (Sekaran dan Bougie, 2013;276 dalam Bahri, 2018;66). Jumlah sample yang digunakan 72 sampel perusahaan.

Jenis data penelitian adalah data kuantitatif. Data kuantitatif adalah data yang berupa angka atau bilangan (Bahri, 2018;85). Data kuantitatif tersebut berupa laporan keuangan tahunan perusahaan sub sektor property dan real estate yang tergabung di Bursa Efek Indonesia periode 2016-2018.

Sumber data penelitian adalah data sekunder. Data sekunder adalah data yang diperoleh secara tidak langsung dan melalui media perantara, berasal dari sumber- 
sumber yang telah ada atau data sudah tersedia dan dikumpulkan oleh pihak lain (Bahri, 2018;82). Data penelitian diperoleh dari laporan keuangan perusahaan sub sektor property dan real estate yang tergabung di Bursa Efek Indonesia periode 2016-2018 yang diperoleh dari website (www.idx.co.id).

Metode pengumpulan data adalah dokumentasi. Dokumentasi merupakan teknik pengumpulan data yang tidak diajukan langsung kepada subjek penelitian, serta dokumen yang diteliti dapat berbagai jenis dan tidak hanya dokumen resmi, biasa berupa buku harian, surat pribadi, laporan, notulen rapat, dan dokumen-dokumen lainnya (Bahri, 2018;103). Dokumentasi yang digunakan berupa laporan keuangan tahunan perusahaan sub sektor property dan real estate yang tergabung di Bursa Efek Indonesia periode 2016-2018.

\section{Teknik Analisis Data}

Metode analisis data yang digunakan dalam penelitian ini antara lain analisis statistik deskriptif untuk mendeskripsikan data yang dilihat dari mean, standar deviasi, nilai minimum, dan nilai maksimum. Uji asumsi klasik yang terdiri dari uji normalitas, uji multikolonieritas, uji heteroskedastisitas dan uji autokorelasi. Persamaan regresi dalam penelitian ini adalah:

$$
\mathrm{Y}=\mathrm{a}+\mathrm{b} 1 \times 1+\mathrm{b} 2 \times 2+\mathrm{b} 3 \times 3+\mathrm{e}
$$

Pengujian hipotesis penelitian dilakukan dengan analisis koefisien determinasi dan uji statistik t (t-test) untuk mengetahui apakah masing-masing variabel independen berpengaruh terhadap variabel dependen.

\section{HASIL PENELITIAN}

\section{Return On Equity (ROE)}

Tabel 4.1

Return On Equity (ROE)

Perusahaan Sub Sektor Property dan Real Estate Periode 2016-2018

\begin{tabular}{|l|c|c|c|}
\multicolumn{4}{c}{ (dalam persentase) } \\
\hline Kode Perusahaan & $\mathbf{2 0 1 6}$ & $\mathbf{2 0 1 7}$ & $\mathbf{2 0 1 8}$ \\
\hline APLN & 9,42 & 16,37 & 1,59 \\
\hline BAPA & 1,70 & 11,00 & 3,87 \\
\hline BEST & 9,92 & 12,56 & 10,13 \\
\hline BSDE & 8,37 & 17,70 & 5,62 \\
\hline CTRA & 8,19 & 6,55 & 7,83 \\
\hline DILD & 5,88 & 4,30 & 2,98 \\
\hline DUTI & 10,79 & 7,78 & 11,97 \\
\hline EMDE & 9,52 & 13,50 & 2,00 \\
\hline GAMA & 0,11 & 0,04 & 0,14 \\
\hline GWSA & 3,24 & 2,82 & 3,05 \\
\hline JRPT & 17,03 & 18,69 & 15,68 \\
\hline KIJA & 7,56 & 2,54 & 1,11 \\
\hline LPCK & 12,72 & 4,77 & 32,21 \\
\hline MDLN & 7,60 & 8,69 & 0,37 \\
\hline MKPI & 32,29 & 26,22 & 19,47 \\
\hline MMLP & 12,16 & 6,28 & 5,30 \\
\hline MTLA & 12,65 & 18,37 & 14,75 \\
\hline PLIN & 31,75 & 29,01 & 17,41 \\
\hline PWON & 16,16 & 15,83 & 18,46 \\
\hline RDTX & 14,22 & 12,02 & 11,56 \\
\hline RODA & 2,24 & 1,49 & 0,00 \\
\hline SMDM & 0,83 & 0,79 & 3,35 \\
\hline SMRA & 9,87 & 6,37 & 7,62 \\
\hline TARA & 0,27 & 0,12 & 0,09 \\
\hline
\end{tabular}

Tabel 4.1 menunjukkan bahwa nilai ROE perusahaan sub sektor property dan real estate pada tahun 2016 hingga 2018 cukup baik meskipun mengalami fluktuasi. Nilai ROE terkecil terdapat pada perusahaan RODA tahun 2018 dan ROE tertinggi terdapat pada perusahaan MKPI pada tahun 2016.

\section{Debt to Equity Ratio (DER)}

Tabel 4.2

Debt to Equity Ratio (DER)

Perusahaan Sub Sektor Property dan Real Estate

Periode 2016-2018

(dalam persentase) 


\begin{tabular}{|l|c|c|c|}
\hline Kode Perusahaan & $\mathbf{2 0 1 6}$ & $\mathbf{2 0 1 7}$ & $\mathbf{2 0 1 8}$ \\
\hline APLN & 1,58 & 1,50 & 1,42 \\
\hline BAPA & 0,67 & 0,49 & 0,35 \\
\hline BEST & 0,54 & 0,49 & 0,51 \\
\hline BSDE & 0,57 & 0,57 & 0,72 \\
\hline CTRA & 1,03 & 1,05 & 1,06 \\
\hline DILD & 1,34 & 1,08 & 1,18 \\
\hline DUTI & 0,24 & 0,27 & 0,34 \\
\hline EMDE & 0,98 & 1,37 & 1,61 \\
\hline GAMA & 0,23 & 0,28 & 0,25 \\
\hline GWSA & 0,07 & 0,08 & 0,09 \\
\hline JRPT & 0,73 & 0,58 & 0,57 \\
\hline KIJA & 0,90 & 0,91 & 0,95 \\
\hline LPCK & 0,33 & 0,61 & 0,25 \\
\hline MDLN & 1,20 & 1,06 & 1,23 \\
\hline MKPI & 0,78 & 0,50 & 0,34 \\
\hline MMLP & 0,21 & 0,15 & 0,15 \\
\hline MTLA & 0,57 & 0,61 & 0,51 \\
\hline PLIN & 1,01 & 3,70 & 3,09 \\
\hline PWON & 0,88 & 0,83 & 0,63 \\
\hline RDTX & 0,15 & 0,11 & 0,09 \\
\hline RODA & 0,24 & 0,41 & 0,46 \\
\hline SMDM & 0,25 & 0,26 & 0,24 \\
\hline SMRA & 1,55 & 1,59 & 1,57 \\
\hline TARA & 0,16 & 0,17 & 0,07 \\
\hline
\end{tabular}

Tabel 4.2 menunjukkan bahwa nilai DER perusahaan sub sektor property dan real estate pada tahun 2016 hingga 2018 mengalami fluktuasi. Sebesar 67\% perusahaan property dan real estate menunjukkan bahwa perusahaan dalam kondisi sehat dan sisanya menunjukkan nilai DER mendekati atau diatas 1 yang menunjukkan perusahaan kurang sehat.

\section{Current Ratio (CR)}

Tabel 4.3

Current Ratio (CR)

Perusahaan Sub Sektor Property dan Real Estate

Periode 2016-2018

(dalam persentase)

\begin{tabular}{|c|c|c|c|}
\hline Kode Perusahaan & 2016 & 2017 & 2018 \\
\hline APLN & 106,78 & 130,65 & 105,57 \\
\hline BAPA & 218,27 & 233,62 & 259,19 \\
\hline BEST & 328,99 & 276,01 & 775,97 \\
\hline BSDE & 293,58 & 237,35 & 336,19 \\
\hline CTRA & 187,53 & 193,64 & 202,03 \\
\hline DILD & 92,15 & 87,91 & 101,01 \\
\hline DUTI & 388,74 & 379,39 & 360,41 \\
\hline EMDE & 2060,62 & 301,65 & 303,33 \\
\hline GAMA & 234,99 & 313,76 & 367,87 \\
\hline GWSA & 880,10 & 826,76 & 780,37 \\
\hline JRPT & 97,48 & 111,48 & 112,75 \\
\hline KIJA & 644,52 & 719,42 & 714,71 \\
\hline LPCK & 464,56 & 581,03 & 595,73 \\
\hline MDLN & 134,45 & 133,02 & 219,46 \\
\hline MKPI & 111,18 & 158,96 & 187,66 \\
\hline MMLP & 85,39 & 132,65 & 134,22 \\
\hline MTLA & 259,47 & 251,05 & 307,75 \\
\hline PLIN & 89,52 & 116,72 & 124,40 \\
\hline PWON & 132,67 & 171,53 & 231,25 \\
\hline RDTX & 325,27 & 461,68 & 449,50 \\
\hline RODA & 393,04 & 546,83 & 451,30 \\
\hline SMDM & 158,19 & 165,42 & 228,42 \\
\hline SMRA & 206,26 & 146,40 & 145,32 \\
\hline TARA & 82,99 & 96,19 & 78,18 \\
\hline
\end{tabular}

Tabel 4.3 menunjukkan bahwa nilai CR perusahaan sub sektor property dan real estate pada tahun 2016 hingga 2018 cukup mengalami fluktuasi. CR berfungsi untuk mengetahui seberapa liquidnya sebuah perusahaan dalam membayar hutang jangka pendeknya. Nilai tertinggi dari CR sebesar 2060,62 tahun 2016 pada perusahaan EMDE yang berarti pada tahun tersebut terdapat banyak data yang 
menganggur yang mengurangi kemampuan perusahaan untuk memperoleh laba. Namun pada tahun selanjutnya perusahaan EMDE dapat mengolah CR menjadi lebih baik.

\section{Return Saham}

\begin{tabular}{|c|c|c|c|}
\hline & & & \\
\hline Kode Perusahaan & 2016 & 2017 & 2018 \\
\hline APLN & $-0,343$ & 0,162 & $-0,274$ \\
\hline BAPA & 1,187 & 0,082 & $-0,177$ \\
\hline BEST & $-0,051$ & 0,097 & $-0,140$ \\
\hline BSDE & 0,006 & $-0,124$ & $-0,086$ \\
\hline CTRA & $-0,360$ & $-0,001$ & $-0,340$ \\
\hline DILD & $-0,187$ & $-0,213$ & 0,024 \\
\hline DUTI & $-0,156$ & $-0,241$ & 0,000 \\
\hline EMDE & 0,299 & 0,052 & -0091 \\
\hline GAMA & 0,000 & 0,140 & 0,175 \\
\hline GWSA & 0,199 & 0,231 & 0,112 \\
\hline JRPT & 0,306 & 0,029 & $-0,286$ \\
\hline KIJA & 0,260 & $-0,183$ & $-0,071$ \\
\hline LPCK & $-0,241$ & $-0,321$ & $-0,473$ \\
\hline MDLN & $-0,337$ & 0,328 & $-0,298$ \\
\hline MKPI & 0,543 & 0,016 & $-0,411$ \\
\hline MMLP & $-0,272$ & 0,011 & $-0,273$ \\
\hline MTLA & 0,115 & 0,245 & 0,117 \\
\hline PLIN & $-0,121$ & $-0,076$ & 0,163 \\
\hline PWON & 0,272 & $-0,052$ & 0,154 \\
\hline RDTX & 0,188 & $-0,342$ & 0,500 \\
\hline RODA & $-0,565$ & 1,118 & $-0,164$ \\
\hline SMDM & 0,084 & 0,155 & 0,314 \\
\hline SMRA & $-0,210$ & $-0,337$ & 0,113 \\
\hline TARA & 0,034 & 0,273 & $-0,100$ \\
\hline
\end{tabular}

Tabel 4.4 menunjukkan bahwa return perusahaan sub sektor property dan real estate pada tahun 2016 hingga 2018 mengalami fluktuasi. Sebesar 51\% perusahaan property dan real estate menunjukkan bahwa perusahaan dalam kondisi kurang sehat dilihat dari return perusahaan yang dibawah angka 0.

\section{Teknik Analisis Data}

\section{Statistik Deskriptif}

Tabel 4.5

Statistik Deskriptif

\begin{tabular}{|l|r|r|r|r|r|}
\hline & \multicolumn{1}{|c|}{ N } & Minimum & \multicolumn{1}{c|}{ Maximum } & \multicolumn{1}{c|}{ Mean } & Std. Devistion \\
\hline ROE & 72 & .004 & 32.285 & 9.51165 & 8.103464 \\
DER & 72 & .066 & 3.701 & .73005 & .643218 \\
CR & 72 & 78.176 & 2060.617 & 310.03374 & 291.176286 \\
RETURN & 72 & -.565 & 1.187 & .00259 & .304730 \\
SAHAM & & & & & \\
Valid N & 72 & & & & \\
(listrise) & & & & & \\
\hline
\end{tabular}

Berdasarkan tabel 4.5 menunjukkan data yang digunakan dalam penelitian sebanyak 72 sampel yang diteliti selama periode 2016-2018.

Variabel Return On Equity (ROE) memiliki nilai terendah sebesar 0,004 yaitu pada PT. Pikko Land Development, Tbk. (RODA), artinya semakin rendah nilai Return On Equity (ROE) maka semakin kecil pula tingkat keuntungan yang dicapai perusahaan dan kurang baik bagi perusahaan dari segi penggunaan modal, nilai tertinggi sebesar 32,285 pada PT. Metropolitan Kentjana, Tbk. (MKPI), Tbk artinya semakin tinggi nilai Return On Equity (ROE) maka semakin besar tingkat keuntungan perusahaan dan semakin baik posisi perusahaan dari segi penggunaan modal. Nilai rata-rata 9,51165, standar deviasi sebesar 8,103464. 
Variabel Debt to Equity Ratio (DER) memiliki nilai terendah sebesar 0,066 yaitu pada PT. Sitara Propertindo, Tbk. (TARA) artinya semakin rendah nilai Debt to Equity Ratio (DER) maka semakin kecil pula kemampuan perusahaan untuk membayar seluruh kewajiban, nilai tertinggi sebesar 3,701 pada PT. Plaza Indonesia Realty Tbk. (PLIN) artinya semakin tinggi nilai Debt to Equity Ratio (DER) maka semakin besar kemampuan perusahaan untuk membayar seluruh kewajibannya. Nilai rata-rata 0,73005 , standar deviasi sebesar 0,643218 .

Variabel Current Ratio (CR) memiliki nilai terendah sebesar 78.176 yaitu PT. Sitara Propertindo, Tbk. (TARA) artinya semakin rendah nilai Current Ratio (CR) maka semakin kecil kemampuan perusahaan untuk melunasi kewajiban jangka pendeknya, nilai tertinggi sebesar 2060,617 pada PT. Megapolitan Developments, Tbk. (EMDE) artinya semakin tinggi nilai Current Ratio (CR) maka dianggap perusahaan mampu untuk melunasi kewajiban jangka pendeknya. Nilai rata-rata 310,03374, standar deviasi sebesar 219,176286.

Variabel return saham memiliki nilai terendah sebesar $-0,565$ yaitu PT. Pikko Land Development, Tbk. (RODA), artinya harga saham sekarang lebih rendah dari harga saham periode sebelumnya berarti terjadi kerugian modal (capital loss), nilai tertinggi sebesar 1,187 yaitu pada PT. Bekasi Asri Pemula, Tbk (BAPA), artinya jika harga saham lebih tinggi dari harga saham sebelumnya berarti terjadi keuntungan modal (capital gain), nilai rata-rata 0,00259, standar deviasi sebesar 0,304730. Standar deviasi lebih tinggi dari nilai rata-rata menunjukkan bahwa sebaran dari variabel data yang besar atau tidak adanya kesenjangan yang cukup besar dari return saham terendah dan tertinggi.

\section{Uji Asumsi Klasik}

\section{Uji Normalitas Data}

Tabel 4.6

Uji Normalitas

One-Sample Kolmogorov-Smirnov Test

\begin{tabular}{|ll|r|}
\hline & & $\begin{array}{r}\text { Unstandardiz } \\
\text { ed Residual }\end{array}$ \\
\hline $\mathrm{N}$ & & 35 \\
Normal Parametersab & Mean & .0000000 \\
& Std. & .49070509 \\
& Deviation & .134 \\
Most Extreme & Absolute & .068 \\
Differences & Positive & -.134 \\
& Negative & .134 \\
Test Statistic & $.116^{c}$ \\
Asymp. Sig. (2-tailed) & & \\
a. Test distribution is Normal. & \\
b. Calculated from data. & \\
c. Lilliefors Significance Correction.
\end{tabular}

Berdasarkan hasil uji normalitas menggunakan one-sample Kolmogorov smirnov test pada tabel 4.6 menunjukkan nilai Kolmogorov-smirnov/test statistic sebesar 0,134 dengan tingkat signifikansi sebesar 0,116. Hasil signifikansi lebih besar dari 0,05 maka dapat disimpulkan data berdistribusi normal.

\section{Uji Multikolonieritas}

Tabel 4.7

Uji Multikolonieritas dengan Variance Inflation Factor (VIF)

Coefficients ${ }^{\mathbf{a}}$

\begin{tabular}{|l|l|}
\hline Model & Collinearity Statistics \\
\hline
\end{tabular}




\begin{tabular}{|ll|r|r|}
\hline & \multicolumn{1}{|c|}{ Tolerance } & \multicolumn{1}{l|}{ VIF } \\
\hline 1 & (Constant) & & \\
& & .872 & 1.147 \\
& LgCR & .700 & 1.428 \\
& LgDER & .785 & 1.274 \\
\hline \multicolumn{2}{|c|}{ LgROE } \\
\multicolumn{2}{|c|}{ a. Dependent Variable: LgRETURN }
\end{tabular}

Return On Equity (ROE) diperoleh tolerance sebesar 0,785 dan VIF sebesar 1,274, untuk Debt to Equity Ratio (DER) diperoleh nilai tolerance sebesar 0,700 dan VIF sebesar 1,428. Current Ratio (CR) diperoleh tolerance sebesar 0,872 dan VIF sebesar 1,147. Maka dapat disimpulkan hasil perhitungan tolerance bahwa tidak ada variabel beban yang memiliki nilai tolerance $<0,10$. Hasil perhitungan variance inflation factor (VIF) juga menunjukkan hal yang sama tidak ada satu variabel independen yang memiliki nilai VIF > 10, sehingga dapat disimpulkan bahwa model regresi pada penelitian ini tidak terjadi multikolonieritas dan model layak digunakan.

\section{Uji Heteroskedastisitas}

\section{Tabel 4.8}

Uji Heteroskedastisitas dengan Spearman's Rho

\begin{tabular}{|c|c|c|c|c|c|c|}
\hline \multicolumn{7}{|c|}{ Correlations } \\
\hline & & & $\mathrm{LgCR}$ & LgDER & LgROE & $\begin{array}{l}\text { Unstandardi } \\
\text { zed Residual }\end{array}$ \\
\hline \multirow{12}{*}{$\begin{array}{l}\text { Spearman } \\
\text { 's rho }\end{array}$} & \multirow{3}{*}{$\mathrm{LgCR}$} & Correlation & 1.000 & $-316^{* \prime}$ & -.132 & -.074 \\
\hline & & Sig. (2-tailed) & & .007 & .269 & .673 \\
\hline & & $\mathrm{N}$ & 72 & 72 & 72 & 35 \\
\hline & \multirow[t]{3}{*}{ LgDER } & $\begin{array}{l}\text { Correlation } \\
\text { Coefficient }\end{array}$ & $-316^{*}$ & 1.000 & .216 & .082 \\
\hline & & Sig. (2-tailed) & .007 & & .068 & .638 \\
\hline & & $\mathrm{N}$ & 72 & 72 & 72 & 35 \\
\hline & \multirow[t]{3}{*}{ LgROE } & $\begin{array}{l}\text { Correlation } \\
\text { Coefficient }\end{array}$ & -.132 & .216 & \multirow[t]{3}{*}{1.000} & \multirow{3}{*}{$\begin{array}{r}.587 \\
35\end{array}$} \\
\hline & & Sig. (2-tailed) & .269 & .068 & & \\
\hline & & $\mathrm{N}$ & 72 & 72 & & \\
\hline & \multirow{3}{*}{$\begin{array}{l}\text { Unstandar } \\
\text { dized } \\
\text { Residual }\end{array}$} & $\begin{array}{l}\text { Correlation } \\
\text { Coefficient }\end{array}$ & -.074 & .082 & .095 & \multirow[t]{3}{*}{1.000} \\
\hline & & Sig. (2-tailed) & .673 & .638 & .587 & \\
\hline & & $\mathrm{N}$ & 35 & 35 & 35 & \\
\hline
\end{tabular}

Berdasarkan hasil uji heteroskodastisitas dengan menggunakan uji spearman's rho pada tabel 4.8 diketahui hasil dari unstandardized residual ROE sebesar 0,587, DER sebesar 0,638, dan CR sebesar 0,673, semua variabel memiliki nilai signifikansi $>0,05$ yang artinya tidak terjadi heteroskodastisitas.

\section{Uji Autokorelasi}

Tabel 4.9

Uji Autokorelasi

Model Summary

\begin{tabular}{|l|l|r|r|r|r|}
\hline Model & R & R Square & $\begin{array}{c}\text { Adjusted R } \\
\text { Square }\end{array}$ & $\begin{array}{c}\text { Std. Error of } \\
\text { the Estimate }\end{array}$ & $\begin{array}{c}\text { Durbin- } \\
\text { Watson }\end{array}$ \\
\hline 1 & $.305^{\mathrm{a}}$ & .093 & .006 & .51390 & 1.510 \\
\hline
\end{tabular}

a. Predictors: (Constant), LgROE, LgCR, LgDER

b. Dependent Variable: LgRETURN

Berdasarkan uji autokorelasi menggunakan Uji Durbin-Watson, dapat dilihat nilai DW sebesar 1,510. Maka tidak terjadi autokorelasi karena DW $-2<1,510<2$.

\section{Analisis Regresi Berganda}

Tabel 4.10

Uji Regresi Linier Berganda

\begin{tabular}{|c|c|c|c|c|c|}
\hline \multirow[b]{2}{*}{ Model } & \multicolumn{2}{|c|}{$\begin{array}{l}\text { Unstandardized } \\
\text { Coefficients }\end{array}$} & \multirow{2}{*}{ 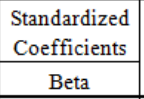 } & \multirow[b]{2}{*}{$\mathrm{t}$} & \multirow[b]{2}{*}{ Sig. } \\
\hline & $\mathrm{B}$ & Std. Error & & & \\
\hline 1 (Constant) & -1.917 & .666 & & -2.877 & .007 \\
\hline $\mathrm{LgCR}$ & .499 & .290 & .315 & 1.720 & .095 \\
\hline LgDER & .203 & .258 & .160 & .785 & .438 \\
\hline $\mathrm{LgROE}$ & -.101 & .138 & -.141 & -.731 & .470 \\
\hline
\end{tabular}


Persamaan regresi berganda dapat dijelaskan sebagai berikut:

Return saham $=-1,917-0,101$ ROE $+0,203$ DER $+0,499$ CR

Berdasarkan tabel 4.10 diperoleh perhitungan konstanta $-1,917$ yang berarti apabila tidak ada variabel ROE, DER, dan CR maka return saham akan menurunan sebesar 1,917. Hasil dari Return On Equity (ROE) sebesar -0,101 menunjukkan setiap penambahan 1 satuan akan menurunkan return saham sebesar 0,101. Hasil dari Debt to Equity Ratio (DER) sebesar 0,203 menunjukkan setiap penambahan 1 satuan akan meningkatkan return saham sebesar 0203. Hasil dari Current Ratio (CR) sebesar 0,499 menunjukkan setiap penambahan 1 satuan akan meningkatkan return saham perusahaan sebesar 0,499.

Koefisien Determinasi $\left(\mathbf{R}^{2}\right)$

Tabel 4.11

Hasil Koefisien Determinasi ( $\mathrm{R}^{2}$ )

Model Summaryb

\begin{tabular}{|l|c|r|r|r|}
\hline Model & $\mathrm{R}$ & $\mathrm{R}$ Square & $\begin{array}{c}\text { Adjusted R } \\
\text { Square }\end{array}$ & $\begin{array}{c}\text { Std. Error of } \\
\text { the Estimate }\end{array}$ \\
\hline 1 & $.305^{\mathrm{a}}$ & .093 & .006 & .51390 \\
\hline
\end{tabular}

a. Predictors: (Constant), LgROE, LgCR, LgDER

b. Dependent Variable: LgRETURN

Hasil koefisien determinasi $\left(\mathrm{R}^{2}\right)$ sebesar 0,006 artinya variabel Return On Equity (ROE), Debt to Equity Ratio (DER), dan Current Ratio (CR) mempunyai pengaruh terhadap return saham sebesar 0,6\% sedangkan sisanya 99,4\% dijelaskan oleh variabel independen yang tidak dimasukkan dalam model ini.

\section{Uji Hipotesis}

1. Return On Equity (ROE)

Hipotesis pertama mengenai Return On Equity (ROE) menunjukkan hasil signfikansi sebesar 0,470 > 0,05. Hasil analisis menunjukkan Return On Equity (ROE) tidak berpengaruh terhadap return saham, sehingga dapat disimpulkan bahwa hipotesis ditolak, karena investor tidak melihat bagaimana cara perusahaan mengelola ekuitas perusahaan.

\section{Debt to Equity Ratio (DER)}

Hipotesis kedua mengenai Debt to Equity Ratio (DER) menunjukkan hasil signifikansi 0,438 > 0,05. Hasil analisis menunjukkan Debt to Equity Ratio (DER) tidak berpengaruh terhadap return saham, sehingga dapat disimpulkan bahwa hipotesis ditolak, karena investor tidak menilai utang dengan seluruh ekuitas perusahaan.

\section{Current Ratio (CR)}

Hipotesis ketiga mengenai Current Ratio (CR) menunjukkan hasil signifikansi sebesar 0,095 > 0,05. Hasil analisis menunjukkan Current Ratio (CR) tidak berpengaruh terhadap return saham, sehingga dapat disimpulkan bahwa hipotesis ditolak, karena investor tidak melihat bagaimana kemampuan perusahaan untuk membayar hutang jangka pendeknya.

\section{PEMBAHASAN}

\section{Pengaruh Return On Equity(ROE) Terhadap Return Saham}

Berdasarkan uji t diperoleh variabel Return On Equity (ROE) tidak mempunyai pengaruh terhadap return saham. Besar kecilnya nilai return on equit (ROE) dalam perusahaan belum dapat mempengaruhi tinggi rendahnya return saham. Selain itu, nilai retun on equity (ROE) tidak berpengaruh terhadap return saham dikarenakan terdapat fenomena perusahaan sub sektor property dan real estate yang semakin melemah pada 
tahun 2016-2018. Dengan melemahnya sektor ini menandakan bahwa nilai laba bersih yang dihasilkan dengan modal perusahaan tidak mempengaruhi investor dalam pengambilan keputusan untuk berinvestasi dan memperoleh keuntungan (return). Pada perusahan PT. Bekasi Asri Pemula, Tbk. (BAPA), Return On Equity (ROE) mengalami kenaikan di tahun 2017 dan return saham mengalami penurunan. Hasil penelitian berbeda dengan penelitian Sepriana dan Saryadi (2017), dan Antara (2014) Return On Equity (ROE) berpengaruh positif dan signifikan terhadap return saham. Hasil penelitian mendukung peneliti terdahulu yaitu penelitian Aisah dan Mandala (2016) Return On Equity (ROE) tidak memiliki pengaruh terhadap return saham.

\section{Pengaruh Debt to Equity Ratio (DER) terhadap return saham}

Berdasarkan uji t diperoleh variabel debt equity ratio (DER) tidak mempunyai pengaruh terhadap return saham. Besar kecilnya nilai Debt to Equity Ratio (DER) dalam perusahaan belum dapat mempengaruhi tinggi rendahnya return saham. Dari fenomena sub sektor property dan real estate yang melemah, berpengaruh terhadap tingkat keuntungan yang diterima oleh perusahaan. Pada perusahaan PT. Jaya Real Property, Tbk. nilai Debt to Equity Ratio (DER) mengalami penurunan di tahun 2017 dan return saham mengalami penurunan. Hasil penelitian menunjukkan bahwa melemahnya sektor property dan real estate memberikan penurunan terhadap return saham pada perusahaan PT. Jaya Real Property, Tbk. berbanding terbalik dengan informasi naik turunnya Debt to Equity Ratio (DER) yang tidak berpengaruh pada keputusan investor atas return saham di Indonesia. Hal ini terjadi karena investor dalam melakukan investasi tidak memandang penting penggunaan hutang sehingga tidak mempengaruhi persepsi investor terhadap keuntungan yang didapat. Hasil penelitian didukung dengan penelitian Puspitadewi dan Rahyuda (2016), Sepriana dan Saryadi (2017), dan Darajat (2018) Debt to Equity Ratio (DER) berpengaruh negatif tidak signifikan terhadap return saham.

\section{Pengaruh Current Ratio(CR) Terhadap Return Saham}

Berdasarkan uji t diperoleh variabel Current Ratio (CR) tidak mempunyai pengaruh terhadap return saham. Besar kecilnya nilai CR dalam perusahaan belum dapat mempengaruhi tinggi rendahnya return saham. Penelitian ini menguatkan fenomena yang terjadi pada sub sektor property dan real estate tahun 2016-2018. Menurunnya pertumbuhan sekor ini mempunyai pengaruh dengan penurunan Current Ratio (CR) perusahaan terhadap return saham. Pada perusahan PT. Modernland Realty, Tbk. Current Ratio (CR) mengalami penurunan di tahun 2017 dan return saham mengalami kenaikan. Hal ini menunjukkan investor dalam mengambil keputusan untuk berinvestasi tidak memandang penting utang lancar dengan aset lancar yang dimiliki perusahaan. Hasil penelitian berbeda dengan penelitian Anisa (2015) Current Ratio (CR) berpengaruh positif dan tidak signifikan terhadap return saham. Hasil penelitian mendukung peneliti terdahulu yaitu penelitian Hayat (2014), dan penelitian Antara (2014) Current Ratio (CR) tidak berpengaruh terhadap return saham.

\section{KESIMPULAN}

\section{Kesimpulan}

Kesimpulan berisi tentang ringkasan singkat dari hasil penelitian dan pembahasan. Pada bagian ini juga menjelaskan keterbatasan penelitian dan saran untuk penelitian selanjutnya. Berdasarkan hasil analisis data dan pembahasan yang telah dilakukan, maka dapat ditarik kesimpulan dari hasil penelitian sebagai berikut:

1. Return On Equity (ROE) tidak berpengaruh terhadap return saham perusahaan sub sektor property dan real estate yang terdaftar di Bursa Efek Indonesia periode 20162018. 
2. Debt to Equity Ratio (DER) tidak berpengaruh terhadap return saham perusahaan sub sektor property dan real estate yang terdaftar di Bursa Efek Indonesia periode 2016-2018.

3. Current Ratio (CR) tidak berpengaruh terhadap return saham perusahaan sub sektor property dan real estate yang terdaftar di Bursa Efek Indonesia periode 2016-2018.

\section{Implikasi}

Implikasi penelitian berdasarkan pembahasan dan kesimpulan yang diuraikan sebagai berikut:

1. Bagi perusahaan, dapat menjadi bahan evaluasi dalam meningkatkan kinerja keuangan perusahaan.

2. Bagi investor, dapat menjadi dasar pertimbangan dalam pengambilan keputusan berinvestasi pada perusahaan sub sektor property dan real estate yang terdaftar di Bursa Efek Indonesia (BEI)

\section{Keterbatasan Penelitian}

Penelitian memiliki beberapa keterbatasan. Adapun keterbatasan penelitian adalah:

1. Objek penelitian terbatas hanya perusahaan sub sektor property dan real estate yang terdaftar di Bursa Efek Indonesia (BEI) sehingga hasil penelitian tidak dapat digeneralisasi.

2. Periode penelitian yang cukup pendek yaitu hanya dilakukan selama tiga tahun (2016-2018), sehingga hasil kurang mencerminkan keadaan pasar modal yang sebenarnya.

3. Variabel yang digunakan dalam penelitian hanya terbatas pada variabel Return On Equity (ROE), Debt to Equity Ratio (DER), dan Current Ratio (CR), sehingga pengaruhnya terhadap return saham sangat kecil dan kurang mencerminkan keadaan yang sebenarnya.

\section{Saran}

Berdasarkan hasil penelitian, kesimpulan, dan keterbatasan penelitian, adapun saran yang mudah-mudahan dapat bermanfaat bagi peneliti selanjutnya yaitu:

1. Peneliti selanjutnya disarankan pada semua sektor industri yang terdaftar di Bursa Efek Indonesia (BEI) sehingga hasilnya dapat digeneralisasikan.

2. Peneliti selanjutnya diharapkan menambah periode penelitian yang lebih lama untuk mengetahui kondisi pasar modal yang sesungguhnya.

3. Peneliti selanjutnya diharapkan menambah rasio keuangan selain ROE, DER dan CR sebagai variabel independen, karena sangat dimungkinkan rasio keuangan lain yang tidak dimasukkan dalam penelitian ini berpengaruh terhadap return saham.

\section{REFERENSI}

Anisa, Nesa. 2015. Analisis Faktor-Faktor yang Mempengaruhi Return Saham Studi Kasus pada Perusahaan Sub Sektor Automotive and Components yang Terdaftar di BEI Periode 2010-2014. Skripsi. Fakultas Ekonomi dan Bisnis. Perbanas Institute.

Antara, Stefanus, Jantje Sepang, dan Ivonne S. Saerang. 2014. Analisis Rasio Likuiditas, Aktivitas, dan Profitabilitas Terhadap Return Saham Perusahaan Wholesale yang Terdaftar di BEI. Jurnal EMBA: Jurnal Riset Ekonomi, Manajemen, Bisnis dan Akuntansi. Vol. 2 No. 3.

Acher, R Wayne dan Ling, C David. 2005. Real Estate Principal, A Value Approach, M. Graw-Hill, New York.

Bahri, Syaiful. 2018. Metodologi Penelitian Bisnis Lengkap dengan Teknik Pengolahan Data SPSS. Penerbit Andi, Yogyakarta. 
Darajat, Zakiah. 2018. Pengaruh ROA, EPS, dan DER Terhadap Return Saham Studi Kasus pada Perusahaan Pertambangan Batubara yang Terdaftar di BEI Periode 20122016. Skripsi. Fakultas Ekonomi. Universitas Negeri Yogyakarta.

Fahmi, Irham. 2012. Manajemen Investasi: Teori Dan Soal Jawaban. Salemba Empat, Jakarta.

Ghazali. 2018. Aplikasi Analisis Multivariate Dengan Program IBM SPSS 25. Edisi 9. PT. Badan Penerbit Universitas Diponegoro, Semarang.

Hayat, Wahid. 2014. Pengaruh Rasio Keuangan Terhadap Return Saham. Skripsi. Fakultas Ekonomi dan Bisnis. Universitas Muhammadiyah Surakarta.

Hermuningsih, Sri. 2012. Pengantar Pasar Modal Indonesia. Edisi 1. UPP STIM YKPN, Yogyakarta.

Hery. 2015. Analisis Laporan Keuangan. CAPS, Yogyakarta.

Jogiyanto. 2014. Teori Portofolio dan Analisis Investasi. Edisi ke 10, BPFE, Yogyakarta.

Kasmir. 2016. Analisis Laporan Keuangan. Raja Grafindo Persada, Jakarta.

Nurhasanah, Rahmalia. 2014. Pengaruh ROA, ROE, dan EPS terhadap Harga Saham (Survey pada Perusahaan LQ 45 yang terdaftar di BEI periode 2007-2011). Skripsi. Jurnal Akuntansi, Fakultas Ekonomi, Universitas Widyatama, Bandung.

Purwitajati, Endah dan I Made Pande Dwiana Putra. 2016. Pengaruh DER pada Return Saham dengan Ukuran Perusahaan sebagai Pemoderasi. E-Jurnal Akuntansi Universitas Udayana. Vol.15.2. Mei 2016.

Puspitadewi, Cokorda Istri Indah dan Henny Rahyuda. 2016. Pengaruh DER, ROA, PER, dan EVA Terhadap Return Saham pada Perusahaan Food dan Baverage di BEI. EJurnal Manajemen Unud. Vol 5, No. 3.

Rahmadewi, Pande Widya dan Nyoman Abundanti. 2018. Pengaruh EPS, PER, CR, dan ROE Terhadap Harga Saham di Bursa Efek Indonesia. E-Jurnal Manajemen Unud. Vol 7, No. 4.

Riyanto, Bambang. 2011. Dasar-dasar pembelanjaan perusahaan. Edisi keempat. BPFE, Yogyakarta.

Ross, S., A. 1977. The Determination of Financial Structure: The Incentive Signaling Approach. The Bell Journal of Economics, Vol 8, No.1, Spring 1977, pp 23-40.

Samsul, Mohamad. 2015. Pasar Modal \& Manajemen Portofolio. Edisi 2. Erlangga, Jakarta. Sawir, Agnes. 2009. Analisis Kinerja Keuangan dan Perencanaan Keuangan Perusahaan. Gramedia Pustaka Utama, Jakarta.

Sepriana, Fransiska dan Saryadi. 2017. Pengaruh ROA, ROE, EPS, PBV, dan DER Terhadap Return Saham. Skripsi. Administrasi Bisnis, Fakultas Ilmu Sosial dan Ilmu Politik. Universitas Diponegoro.

Sugiarti dan Surachman Siti Aisjah. 2015. Pengaruh Kinerja Keuangan Perusahaan Terhadap Return Saham Studi pada Perusahaan Manufaktur yang Terdaftar di BEI. Skripsi. Fakultas Ekonomi dan Bisnis. Universitas Brawijaya.

Susilowati, Yeye dan Tri Turyanto. 2011. Reaksi Signal Rasio Profitabilitas dan Rasio Solvabilitas terhadap Return Saham Perusahaan Manufaktur yang Terdaftar di Bursa Efek Indonesia. Jurnal Dinamika Keuangan dan Perbankan. Vol 3 No 1. Mei 2011.

Syamsudin. 2009. Manajemen Keuangan Perusahaan. PT. Raja Grafindo Persada, Jakarta. www.idx.co.id 